\title{
UNION COMPETITION AND STRIKES: THE NEED FOR ANALYSIS AT THE SECTOR LEVEL
}

\author{
AGNES AKKERMAN*
}

\begin{abstract}
International comparative research has found that strike incidence is higher where two or more unions bargain with an employer ("multi-unionism"), as is common in most European countries, than where only one union does, all else equal. Two proposed explanations for this relationship, both invoking inter-union rivalry as the main dynamic, are that under multi-unionism, unions (a) make propagandistic use of strikes to attract members, or (b) compete with each other by bidding up bargaining demands. To date, the evidence bearing on these hypotheses has been equivocal because, the author argues, researchers have focused on activity at the national level rather than at the lower levels that are more commonly the nexus for strike formation. The author performs empirical tests using industry-sector-level data for seven European countries for the years 1990-2006, and finds evidence clearly favoring the competitive bargaining hypothesis over the propaganda hypothesis.
\end{abstract}

$\mathbf{I}_{\mathrm{e}}$ $\mathrm{n}$ this study, I seek to explain a paradoxical effect of multi-unionism on strike incidence: although union power within bargaining structures is lower when two or more unions negotiate with the employer (the definition of "multi-unionism") than when only one does, the mainly comparative studies of this subject report higher strike activity under multi-unionism. Unlike in the United States, where multi-unionism disappeared after the Wagner Act in 1935 (Gould 2004:29), exclusive jurisdiction is the exception in Europe

*The author is Assistant Professor of Public Administration at the Institute for Management Research, Nijmegen School of Management, Radboud University, Nijmegen, the Netherlands, and Senior Researcher at the Department of Sociology, Utrecht University, the Netherlands. She thanks Jim Allen for his helpful comments.

A data appendix with additional results, and copies of the computer programs used to generate the results presented in the paper, are available from the author at the Department of Political Science and Public Administration, Nijmegen School of Management, Radboud University Nijmegen, P.O. Box 9108, 6500 HK Nijmegen, The Netherlands; a.akkerman@fm.ru.nl.
(Visser 1992). There, it is very common for more than one union to be recognized as a bargaining partner by the employer, both at the level of the individual firm and at the sector level. At the national level, multiunionism can be caused by the division of worker representation between two or more union confederations. Of the 27 European Union member states, $85 \%$ have more than one labor union confederation; Hungary, at the extreme, has six. Most labor union confederations are divided along political $(50 \%)$, religious $(25 \%)$, or occupational (status) lines $(25 \%)$, or a combination of these three (Eurofound 2006, 2007). Even in the four countries with just one union confederation - the United Kingdom, Austria, Ireland, and Latvia-multi-union bargaining is not unknown: unaffiliated unions and union representation by several unions within the same confederation are found in all four of these nations. Thus, the industrial relations environment in Europe differs sharply from that in North America, where one particular union has the exclusive right to represent employees in a particular firm. 
Both theoretical and empirical studies point to dramatic economic consequences of multi-unionism. Multi-unionism has been found to elevate unemployment, reduce efficiency among firms, restrain productivity growth, push wages up, and, above all, increase strike incidence. ${ }^{1}$ The main body of literature, consisting of cross-national comparative analyses of strikes, suggests a relationship between strike incidence and the number of confederations within a country. Countries with more than one confederation experience higher rates of strikes than do those with a single confederation. Most of these studies explicitly or implicitly posit that this higher incidence of strikes can be explained by the propagandistic value of strikes to labor unions, which compete with one another for membership. The higher incidence of strikes is thus attributed to union rivalry. A second, smaller body of literature is based mainly on economic analysis. These studies, which all concern U.K. industrial relations, find that the number of unions bargaining with an employer is linked both to economic output and to the incidence of industrial conflict. Like the other, larger set of studies, these studies identify union rivalry as a possible cause of industrial conflict. However, this second school of thought differs considerably from the first in its underlying reasoning: the main spur to strike activity is not the propagandistic value of strikes, but rather "inter-union jealousy" and a lack of cooperation between unions, which together encourage unions to drive up wage demands (Oswald 1979). These two hypotheses contradict each other in their analyses of the mechanisms by which multi-unionism leads to competition between unions, and hence to more strike activity.

\footnotetext{
${ }^{1}$ For multi-unionism's effects on unemployment, inefficiency, and product growth, see Pohjola (1984); for its effects on wages and strike incidence, see Webb and Webb 1897; Galenson 1940; Ross and Irwin 1951; Gitlow 1952; Lester 1958; Ross and Hartman 1960; Krislov 1960; Clegg 1976; Freeman and Britain 1977; Korpi and Shalev 1979; Visser 1987; Franzosi 1989; Battista 1991; Cohn 1993; Ingram et al. 1993; Machin et al. 1993; Franzosi 1995; and Stout 1995.
}

Does the higher strike incidence result from competition for members, or from competing wage demands? Competition for members would be relevant only among unions without strictly demarcated membership bases, whose potential membership therefore overlaps. Inter-union competition expressed through wage demands, in contrast, would be relevant among unions with distinct memberships.

In this article I attempt to reinvigorate the study of labor union competition and its impact on strike incidence by examining the theoretical paradox of multi-unionism, and testing the two contradictory hypotheses presented above. I also aim at improving the methods used by traditional cross-national studies to test the relationship between the number of labor unions and strike frequency. Traditional tests have been flawed because both their dependent variable-strike frequency-and their independent variablecompetition between labor unions-have been measured by indicators at the national level, whereas most strikes and competition between labor unions occur at the sub-national level, such as within industrial sectors or individual companies. Finally, this study, which investigates seven countries and four industrial sectors, represents a significant expansion of the empirical research and goes beyond the one-sector, one-country, unifiedlabor-movement studies that economists have conducted exclusively in Britain. This will enable a cross-sector evaluation of the two competition hypotheses in countries with a divided labor movement.

\section{The Empirical Status of Union Competition}

Ross and Irwin (1951) and Ross and Hartman (1960) are classic studies of strike activity. On the basis of their research into strikes in five countries, Ross and Irwin concluded that strike levels seemed to increase in countries where the labor force was divided into multiple federations and to decrease when a unified labor force was present. In the latter countries, strikes were eventually expected to disappear. In a more extensive follow-up study in 1960, Ross and Hartman tested their thesis of the "withering away" of 
strikes in countries with a unified labor force. Although all fifteen of the countries studied showed decreasing strike activity, they also displayed remarkably divergent levels of strike activity. One explanation for this divergence was the existence of a divided labor movement, which implies competition between unions for members. Continuous competition for better settlements would encourage strikes. Labor unions attract new members by negotiating better working conditions, and the presence of several labor unions is likely to drive up their demands:

Rival unionism is a potent cause of strikes where rivalry is pursued on the basis of comparative militancy in pressing grievances and comparative gains in collective bargaining. A labour organization must attempt to match the achievements of its rival or rivals and must secure even greater benefits, if possible, regardless of the amount of resistance to be overcome. (Ross and Hartman 1960:65-66)

Ross and Hartman distinguished two dimensions of strike activity: strike frequency and strike duration. Ranking the fifteen countries under investigation, they observed four patterns of strike activity: two Northern European patterns, displaying low levels of strike frequency; and a Northern American pattern and Mediterranean-Asian pattern, displaying higher strike frequency. These patterns seem to reveal a clear positive association between the incidence of strikes and the presence of a divided labor movement.

However, the presence of a divided labor movement alone was insufficient to explain the observed incidence of strikes: some of the countries with a divided labor movement had high strike incidence, and some did not. The Netherlands was the exception to the Northern European pattern: it had a highly divided labor movement, yet displayed low strike frequency. Although the labor unions of the Netherlands and France had comparable religious and political divisions, the peaceful cooperation among Dutch labor unions was in stark contrast to the inter-union rivalry in France. Thus, there must be more to the observed relationship between strike frequency and divisions within the labor movement than union rivalry.

The second conclusion of Ross and Hart- man's empirical study was that no correlation existed between strike duration and labor movement division. To explain the variation in strike frequencies within the group of countries with a divided labor movement, Ross and Hartman introduced an institutional factor: cooperation at the national level, combined with the possibility of serving labor interests in the political arena, would reduce the incidence of strikes even in the presence of a divided labor movement, they hypothesized. Although this explanation may hold true for the Netherlands, it seems somewhat ad hoc.

Another author who tried to explain anomalies in the assumed relationship between labor movement divisions and strike incidence was Clegg (1976). Also assuming union rivalry to be the cause of high strike frequencies, Clegg offered institutional factors to explain exceptions like the Dutch case. In particular, based on a theory of collective bargaining he developed by comparing the experiences of six countries, Clegg asserted that the bargaining structure is responsible for the observed differences in strike incidence: strikes at lower bargaining levels are supposedly cheaper for unions, because fewer strikers are needed than at the sector or national level. This should explain the high strike incidence in the United States, where bargaining occurs at the level of individual firms. Clegg argued that arbitration institutions, such as the Swedish Labor Court and the Dutch peace-keeping resolutions, account for the remaining variation in strike activity among countries with nationally based bargaining systems. Strike funds may also temper strike frequency. The idea that strike funds decrease strike frequency may seem paradoxical, but Clegg suggested that unions with large strike funds at their disposal tend to wish to preserve these savings rather than spend them to finance strikes.

Clegg used these factors to explain the differences in strike frequency between, on the one hand, France, Australia, and the United Kingdom, where strike frequency was high, and, on the other hand, Germany and Sweden, where strike frequency was low. However, this could not explain the high levels of strikes in the United States, 
which had conflict resolution mechanisms comparable to Germany's and Sweden's (Clegg 1976:71). According to Clegg, union rivalry explains this anomaly. Rivalry within and between unions (especially in France) pushed up the incidence of strikes. The high incidence of strikes was an interaction effect of company-level bargaining and inter-union rivalry. Clegg argued that a decentralized bargaining structure leads to fierce competition within and between labor unions, thus implying that union competition is the real mechanism producing higher levels of strike frequency.

Korpi and Shalev (1979) also pointed to divisions within the labor movement to explain the incidence of strikes. They suggested that, rather than institutional factors such as the level at which bargaining occurs and conflict resolution structures, it is the power relations between capital and labor that explain strike frequencies. This factor determines the institutional arrangement within a country, which may facilitate the employee representatives' use of the political arena for interest representation; this, in turn, may reduce open conflict with employers.

For Korpi and Shalev, the relationship between strike frequency and labor movement divisions depends on a number of political factors, one being the way employees are organized, or, more precisely, whether employees are represented by a united front of unions. Korpi and Shalev stated that the presence of a unified labor front is a precondition for influencing political decision-making. A divided labor movement produces a weakened labor class, which is less able to influence institutional arrangements and is left with labor conflict as a last resort:

A ... desideratum is that the working class be characterized by a substantial degree of organizational unit, that is coordination between the different segments and arms of the labour movement and influence over the constituents within them. Unless this ... precondition is met, neither capital nor the representatives of state would be likely to regard political exchange as a credible option. (Korpi and Shalev 1979:180)

From this perspective, the link between high strike frequency and a divided labor movement is not caused by competition for members among unions, as the institutionalist approach suggests, but by the failure of employees to form a united front when dealing with employers and government.

Korpi and Shalev developed their theory based on a case study of Sweden, then tested it through an international comparison of 18 countries. However, their alternative explanation was still equivocal: as in previous studies, the Netherlands remained an unexplained exception. Moreover, Korpi and Shalev uncovered a new anomaly: Switzerland. Both countries showed low strike activity. In these particular countries, Korpi and Shalev suggested, labor is able to use the political arena, despite the fact that various labor union federations are present. They assumed that in pillarized ${ }^{2}$ societies, such as the Netherlands and Switzerland, the weakness of a divided labor movement is compensated for by their formation of coalitions with likeminded political parties.

In their efforts to explain differences in strike activity between countries, the comparativists find a relationship between divisions in labor movements and strike frequency, which they explain with a mechanism on a quite different level. Only Korpi and Shalev cited national-level factors to explain the relationship; both Clegg and the team of Ross and Hartman attributed differences in national strike levels to sector-level-competition between unions. Competition on the national level may have been relevant at the time of their studies, but it is certainly not the level at which most bargaining takes place in today's Europe. Due to processes of decentralization in most Western European states, most bargaining now takes place at the sector or company level (Traxler et al. 2001). In essence, competition for members does not refer to divisions between central union

\footnotetext{
2"Pillarization" refers to a vertically divided society, split along religious or ideological lines (or both), with each group having its own "pillar": for example, the Catholic, Protestant, and Socialist pillars, each of which had its own political parties, labor unions, broadcasting associations, schools, and other institutions. Examples of pillarization are the Netherlands, Austria, and Belgium. Pillarized entities are also referred to as "consociational"; see Lijphart (1968).
} 
confederations, but resembles what in British strike research is called "multi-unionism."

Although the United Kingdom is not characterized by a divided labor movement, multi-unionism is common in British plants and companies (Machin et al. 1993), and the United Kingdom, surprisingly, is the only country for which internationally published research has been conducted on the effects of multi-unionism. Several studies have investigated the effect of multi-unionism on strikes in the United Kingdom and have found a positive relationship (Stewart 1987; Ingram et al. 1993; Machin et al. 1993). The effect of multi-unionism is particularly strong in manufacturing (Dobson 1997). In the case of the United Kingdom, multi-unionism is not caused by political or religious splits among unions; at the national level no such splits exist in the unions confederation. Although multi-unionism in the United Kingdom is not a simple phenomenon, and has been especially difficult to characterize since the waves of mergers of small unions into large "general" unions (Edwards et al. 1992:38; Ebbinghaus and Waddington 2000:706-16), fundamentally it is rooted in the organization of different groups of workers by specific unions. The lack of coordination over bargaining claims and the presence of "interunion jealousy" encourage unions to compete by driving up wage demands (Oswald 1979). This explains the association between higher wage levels and multi-unionism, but does not explain the observed higher strike incidence under multi-unionism.

\section{The Need for a Comparison Based on a Sector-Level Analysis}

The strike frequency studies I have discussed are alike in concluding that there is a positive relationship between divided labor movements and strike frequencies. Nevertheless, persistent anomalies have occurred, and these have repeatedly been explained by the presumed dampening effect of national institutional factors. Although these suggestions have surface plausibility, they do not offer a systematic explanation for the observed relationship.

At least two factors account for the am- biguous empirical results of investigations into the relationship between a divided labor movement and strike frequencies. The first factor is theorists' oversimplification of the effect of competition, and the second factor involves methodological issues.

\section{Theoretical Considerations}

Comparative studies suggest competition as the main cause of the observed positive relationship between multi-unionism and strikes. The argument that strikes are used as a marketing tool is compelling, and the suggested effect seems plausible at face value. Closer examination, however, reveals a paradox. This paradox can best be understood when we view the union's decision to engage in industrial conflict from the perspective of the leadership. The leadership will assess the potential benefits of a strike. This judgment will be based on (a) the potential value of the concession from the employer-which may consist of improvements, like wage increases, or the prevention of a deterioration in employment conditions-and (b) the probability that a strike will succeed in forcing the employer to make such a concession (Hicks 1963). The labor union assesses the probability of such a concession on the basis of, among other things, its bargaining power and the bargaining power of the employer. Assuming that a union's membership is an important determinant of its bargaining power (see Britt and Galle 1972; Crouch 1982; Gramm 1986; Martin 1992), this implies that a labor union in competition with other unions has to share its potential bargaining power with other unions (Akkerman et al. 1995). This problem will tend to weaken such a union's bargaining power, irrespective of the power of the employer (assuming that the total rate of unionization is constant). The probability of winning a strike will therefore be smaller for unions that negotiate within a bargaining unit in which more than one union operates. The reduced chances of winning a strike will reduce the expected utility of a strike for these unions.

A possible effect of this weakened position is reduced effectiveness of strikes under multi-unionism. For example, an employer 
who is aware that a union is weakened by this dynamic may force the union into a strike. However, the ultimate decision to call a strike rests with the union, which is not likely to take the fatal step of initiating a foredoomed strike. An unsuccessful strike would not improve the membership's trust in the union in the long run and would be an implausible strategy for a union to follow in order to retain or enlarge its membership. A more plausible effect of the reduced expected utility of striking is therefore a reduced incidence of strikes. By this reasoning, union splits should reduce rather than increase strike activity.

Two other considerations, however, would lead to the opposite expectation, namely, that union splits should result in higher strike incidence. First, union splits are likely to result from divergent interests. These divergent interests create various, sometimes even contradictory, claims, which the employer may not be able to fulfill (Machin et al. 1993:283). This increases the probability that the demands of at least one of the unions will not be satisfied, thereby increasing the probability of a strike. Moreover, the employer, who is not fully informed even when bargaining with one union, will face further informational difficulties when assessing the costs and probabilities of the unions' strategies. The employer needs to assess not only the probability of a strike by one or other of the unions, but also the probability of the unions cooperating in a strike. This increases the scope for misjudgments, which again results in a higher probability of a strike. In cases where rival strikes occur, these would orginate from substantive reasons: unfulfilled bargaining claims. The effect of multi-unionism should therefore be greater in heterogeneous sectors where workers' interests diverge the most (hypothesis I). (Machin et al. 1993.)

An alternative explanation for the paradox is that labor's weakness may drive unions into a struggle to survive. In this struggle, maintaining and increasing the membership is of vital importance to unions, and this imperative may encourage them to compete for members. Unions may compete for new, as yet unaffiliated workers, but equally for each other's existing members. Indeed, the first category may be more difficult to win over than the second, since existing members of other unions have already shown their willingness to engage in unionism. Any overlap in (potential) membership will increase the chances of a strike. Overlap can be based on similarities in occupation, job level, political background, and so on. In this case, rival strikes would orginate not from substantive motives, but purely from membership competition. If this is true, the effect of multi-unionism will be stronger in homogeneous sectors, where the overlap in membership is largest (hypothesis II). (Akkerman 1997.)

At the same time, multi-unionism does not by definition rule out the possibility of cooperation between unions. When interests converge and overlap in membership is absent or only moderate, unions may see opportunities to join forces. They may jointly bargain with the employer (that is, engage in "single-table bargaining"; Chaison 1996:86), and may decide to join forces in calling a strike. In fact, cooperation can also be the result of severe competition: unions may imitate each other and all call a strike in order to prevent their members from defecting to their rivals on strike. In such situations competition causes involuntary "cooperation" (Akkerman 2000). Whatever the motives for cooperation are, for the argument of this article it is important to establish its consequences. The bargaining situations in which all unions cooperate, in fact acting as one union, will lead, ceteris paribus, to the same strike probabilities as the single-union situation, theoretically.

\section{Methodological Issues}

International comparisons have suffered not only from a limited theoretical base, but also from three methodological limitations. First, the international comparisons I have discussed may have been distorted by conflict-dampening or conflict-intensifying factors at the national level. Ross and Hartman have already explored the possibility of dampening factors at the national level. Although the presence of such factors may reduce the number of strikes, they do not nullify the relationship entirely. Even where strike frequencies are low by international 
comparison, the strikes that do occur may still be caused by competition.

Second, the studies that observe a relationship between a divided labor movement and strike frequencies test the suggested effect of union competition on aggregated data: the strike frequency across an entire country. This is questionable because union competition seems a phenomenon less likely to occur at the national level than at lower levels. Collective bargaining and employee representation occur mainly at the company or sector level. Particularly at the sector level, a wide variation in the number of labor unions exists. Clegg's suggestion that there is an interaction effect between the bargaining level and union competition refers implicitly to the sector or company level. Furthermore, the independent variables are not alone in being mainly sector- or company-level phenomena, in this case; strikes are, too, as shown by the fact that strike incidence can differ significantly between sectors (see Campolieti et al. 2005). It is not the federation that calls a strike, but the affiliated union. The use of aggregated data obscures the level at which the proposed explanation of union competition is to be identified. Wheeler (1984:263) argued that "it is not acceptable ... to justify a variable on the micro level and measure it on the macro level." An empirical test using data collected at the actual bargaining level therefore holds the promise of providing improved accuracy.

Third, the comparative studies fail to submit their findings to a statistical test. Until the null hypothesis has been thoroughly tested, the proposed relation can claim only conjectural status.

In this article, the relationship between strike frequencies and multi-unionism is subjected to a statistical test by means of a multilevel analysis. This enables a determination of whether the effect of multi-unionism on strike frequency occurs at the national level or the sector level, and whether that effect is stronger in heterogeneous sectors or in homogeneous sectors.

The studies of multi-unionism in the United Kingdom in the 1980 s benefited from more up-to-date statistical methods; however, since a clear characterization of British multi- unionism is not available, the U.K. case studies cannot distinguish between substantive competition and membership competition. International comparative analyses at the sector level are therefore required.

\section{Data and Method}

The main argument of this article is that the effect of multi-unionism should be studied at the level where bargaining takes place, which in this analysis is the sector level. Although in some European countries, such as the United Kingdom, company-level bargaining is dominant, sector-level bargaining is dominant in the Western European countries in my sample. In all of these countries, however, company-level bargaining also occurs, and bargaining at the company or sector level is not exclusive; multi-level bargaining is prevalent (Traxler et al. 2001). Under multi-level bargaining, sector-level agreements consist of binding or non-binding agreements on certain issues that apply to companies, while other issues are left for company-level bargaining. Nevertheless, all seven countries that are examined in the present study have been characterized by various authors as countries where sector-level bargaining predominates (Traxler et al. 2001; OECD 2004; ETUI 2007).

The multi-level comparison of strike frequencies is limited to the seven countries presented in Table 2. The limited availability of data on the number of unions at the sector level reduced not only the number of countries the analysis could include, but also the number of sectors. Since not every sector is present in every selected country, the sectors also had to be selected carefully. To avoid the problem of missing observations, I selected four sectors that were present in all seven countries. Also, the public sector was deleted from the sample, to avoid problems that would arise because of international differences in the legal status of strikes by civil servants.

\section{Dependent Variable}

I use strike frequency as the dependent variable. This measure for industrial conflict has some serious drawbacks. Several scholars 
Table 1. Strike Incidence (the Dependent Variable), 1990-2006, by Sector

(Manufacturing, Construction, Trade, and Transport) ${ }^{\mathrm{a}}$ in Seven Countries.

\begin{tabular}{lcccccc}
\hline Country & Manufacturing & Construction & Trade & Transport & Total & Mean \\
\hline Sweden & 8.7 & 1.5 & 0.8 & 5.8 & 16.8 & 4.2 \\
Switzerland & 2.1 & 0.7 & 0.2 & 0.3 & 3.3 & 0.8 \\
Norway & 3 & 1.4 & 1.4 & 2.9 & 8.7 & 0.5 \\
Netherlands & 7.8 & 0.4 & 6.9 & 6.9 & 22 & 5.5 \\
Belgium & 33.1 & 0.3 & 3.9 & 2.5 & 39.8 & 10 \\
Austria & 0.3 & 0 & 0 & 0 & 0.3 & 0.1 \\
Italy & 354.1 & 51.7 & 22.4 & 144.6 & 572.8 & 143 \\
Total & 409.1 & 56 & 35.5 & 163 & 663.6 & 166 \\
Mean & 58.4 & 8 & 5 & 23.3 & 94.8 & 23.7 \\
\hline
\end{tabular}

Source: ILO, Yearbook of Labour Statistics $(1997,2006)$

aThese sectors correspond with the International Standard Industrial Classification of all Economic Activities (ISEC-rev.3): Manufacturing corresponds to the ISIC category D, "Manufacturing"; Construction to category F, "Construction"; Trade to categories G+H, "Wholesale, Retail Trade, and Hotels and Restaurants"; and Transport to category I, "Transport, Storage, and Communication."

have cited potential methodological problems arising from differences across countries in the definition and measurement of "strikes" (Edwards and Hyman 1994:252, 253; Stokke 2001:248). Some countries include short strikes in strike statistics, and others do not; ${ }^{3}$ some define strikes to include a range of collective actions, and others count only official strikes. Therefore, strike duration, the number of employees on strike, or a combination of those variables, such as working days lost to strikes, is generally preferable to strike frequency as a measure of strike activity, especially when the economic or social impact of strikes is under investigation. ${ }^{4}$

Granted that strike frequency may not be the most reliable indicator of industrial conflict in international comparisons, however, I argue that for the purposes of the present study, it is the most valid dependent variable. First, a competition-motivated decision to call a strike will most likely be reflected in the number of strikes. The other indicators are

\footnotetext{
${ }^{3}$ Among my selected countries, this holds for Norway, Sweden, and Switzerland. A rather simple solution to this problem, proposed by Edward and Hyman (1994), would be to omit short strikes for every country. However, the ILO yearbook only provides aggregated data, which makes it impossible to identify individual strikes and their duration.

${ }^{4}$ However, Hyman (1989:18-19) was also skeptical about the reliability of the number of workers involved in a strike and working days lost.
}

less straightforward, because union leaders are less able to control the other characteristics of a strike: strike duration is mainly determined by the resistance of the employer (Hicks 1963; Crouch 1982), and the number of employees on strike is largely dependent on the number of employees, or unionized employees, within the sector (Akkerman etal. 1995). Second, this paper reinvestigates the association found in previous international comparisons in which strike frequency was either the sole dependent variable or one of a set of dependent variables. It would be impossible to compare previous studies with this study if a different dependent variable were used. Finally, the problem of the comparability of strike frequency is less urgent at the sector level than at the national level, as will be explained below.

Strikes are, of course, not the only means unions use to force employers to give in to their demands. Demonstrations, overtime bans, and work-to-rule or "go slow" actions, for example, are alternatives to a costly strike. Given that unions use alternative means of protest, and that competition also affects the use of these means, restricting the analysis to strikes implies an underestimation of the effects of competition on industrial conflict.

I use the statistics on strike frequency provided by the ILO Yearbook of Labor Statistics (1997, 2006), from which data concerning the number of strikes in the selected sectors 
Table 2. Number of Unions in Four Sectors

(Manufacturing, Construction, Trade, and Transport) in Seven Countries, 1992.

\begin{tabular}{lcccccc}
\hline Country & Manufacturing & Construction & Trade & Transport & Total & Mean \\
\hline Sweden & 14 & 11 & 9 & 10 & 44 & 11 \\
Switzerland & 22 & 6 & 10 & 20 & 58 & 14.5 \\
Norway & 19 & 4 & 7 & 23 & 53 & 13.3 \\
Netherlands & 33 & 6 & 14 & 24 & 77 & 19.3 \\
Belgium & 17 & 5 & 6 & 9 & 37 & 9.3 \\
Austria & 7 & 2 & 1 & 2 & 12 & 3 \\
Italy & 18 & 3 & 3 & 7 & 31 & 7.75 \\
Total & 130 & 37 & 50 & 95 & 212 & 53 \\
Mean & 18.6 & 5.3 & 7.1 & 13.6 & 30.3 & 7.5 \\
\hline
\end{tabular}

Source: Ebbinghaus and Visser (2000).

within a 17-year period $(1990-2006)^{5}$ were extracted. To mitigate the effects of extreme values (such as in Italy), I calculated the log of the strike frequencies.

Table 1 shows huge variance between countries, similar to the variance observed by international comparative studies. However, the variance between sectors also appears to be large. Strike incidence is consistently higher in the manufacturing and transport sectors than in other sectors, indicating that sector-level effects may be present.

\section{Explanatory Variables}

The number of trade unions in a sector is used to proxy multi-unionism. The number of unions by sector, taken from Ebbinghaus and Visser's (2000) database, ${ }^{6}$ is shown in Table 2.

\section{Control Variables}

The dependent variable, strike frequency, is not scale-free and is likely to reflect the size of the work force of a nation or sector. To exclude the possibility that the relationship between the number of unions and strike frequency is caused by the size of a sector (and therefore the number of potential

${ }^{5}$ For some of the more recent years, data collection failed for some countries, such as Belgium, because of too many missing cases.

${ }^{6}$ Unpublished, but made available to the author. conflicts), I control for number of employees (ILO 1997, 2006) and number of enterprises in the sector (OECD 2007). To isolate the effect of multi-unionism from the effects of the business cycle (Campolieti et al. 2005), I also control for employment rate and change in GDP (OECD 2007).

\section{The Heterogeneity/ \\ Homogeneity of the Sectors}

The hypotheses distinguish between homogeneous sectors and heterogeneous sectors. This could refer to several characteristics of a sector's work force, such as occupation, educational level, age, gender, and religious or political background. Divisions among unions in Europe are based mainly on either religious background, political background, or occupation. Since information on employees' religious and political background is not available, I focus on an indicator for the degree of occupational heterogeneity within the work force of a sector: a Gini-Hirschman index of occupational heterogeneity. ${ }^{8}$ This measure indicates the standardized number

\footnotetext{
${ }^{7}$ Another relevant control variable is union density. Unfortunately, comparable data on union density at the sector level are not available for all seven countries in the sample. An analysis controlling for union density was, however, performed using a smaller data set; for the results, see note 11 .

${ }^{8}$ Information on the political and religious backgrounds (of workers) is protected by EU directive 94/46/ EG, and processing of this information is prohibited.
} 
Table 3. Classification of

Sector by Degree of Heterogeneity.

\begin{tabular}{llcl}
\hline ISIC & Sector & $\begin{array}{c}\text { Gini } \\
\text { Hirschman } \\
\text { Index }\end{array}$ & Classification \\
\hline D & Manufacturing & & Heterogeneous \\
& Food & 15 & Heterogeneous \\
& Chemicals & 16 & Heterogeneous \\
& Metal & 15 & Heterogeneous \\
& Other & 30 & Heterogeneous \\
F & Construction & 6.6 & Homogeneous \\
G+H & Trade & & Middle \\
& Trade & 8 & Homogeneous \\
& Hotels etc. & 27 & Heterogeneous \\
I & Transport & & Middle \\
& Transport & 5.5 & Homogeneous \\
& Communication & 10 & Middle \\
\hline
\end{tabular}

of occupations in a sector. When occupations in a work force are concentrated in one category, the Gini-Hirschman index equals 1 , indicating an extremely homogeneous work force. The lower the concentration, the higher the indicator, and the more heterogeneous the work force in terms of the number of occupations. This Gini-Hirschman indicator controls for the distribution over occupational categories within sectors (Cörvers et al. 2006). Table 3 shows the Gini-Hirschman index for the selected sectors. ${ }^{9}$

On the basis of the Gini-Hirschman index, the sectors were classified according to their degree of heterogeneity. Transport and trade are harder to classify than manufacturing and construction, because of the diverging levels of heterogeneity of the categories within these sectors. A finding that the effect of the number of unions on strike frequency is strongest in manufacturing and weakest in construction would be consistent with hypothesis I; conversely, a finding that the

\footnotetext{
${ }^{9}$ This indicator is based on a Gini-Hirschman index of the occupational composition of Dutch sectors. Since the activities in the sectors will be similar in the selected countries, I assume that this Gini-Hirschman index is a plausible indicator for sectors in all countries in the sample. Calculated at the request of the author by the Research Center for Education and Labour Market, Faculty of Economics and Business Administration, University of Maastricht.
}

effects are strongest in construction and weakest in manufacturing would confirm hypothesis II.

\section{Method}

To address the methodological problems associated with the international comparative studies discussed, I estimate the effects of multi-unionism by means of a multi-level analysis. ${ }^{10}$ This enables me to estimate (a) the extent to which strike frequencies differ between countries and (b) the extent to which this can be explained by sector-level characteristics. The multi-level analysis also partly resolves the reliability issue that arises in comparing strike frequencies: we may safely assume that the comparison of strikes at the sector level is not distorted by different methods of measures of strikes, which means that making comparisons within countries is less problematic (Edwards and Hyman 1994:252). I use years as cases for each country and sector, which means that the cases (years) are nested in countries, and in sectors. In order to control for this nested structure, I distinguish a third level in the multi-level analysis: years.

\section{Results}

The multi-level analysis generates information of three kinds. First, it estimates the effect of the explanatory variables, just like an ordinary regression. This effect is called the fixed effect, which can be evaluated by a t-test. Second, it estimates the random effects, or the variance. This variance is divided between variance at the highest level and variance at each lower level. The analysis of the effect of multi-unionism on strike frequencies distinguishes between years at the lowest level, sectors at the middle level, and countries at the highest level. In an empty model, that is, a model without explanatory variables, these random effects inform us about the degree of variance at the various levels distinguished (Snijders and Bosker 1999). The variance at the sector level shows how the sectors differ

\footnotetext{
${ }^{10}$ The multi-level analysis was performed with MLwiN version 2.02 .
} 
Table 4. Results of the Multilevel Analysis of the (ln) Number of Strikes.

\begin{tabular}{|c|c|c|c|c|}
\hline Variable & Model O & Model 1 & Model 2 & Model 3 \\
\hline \multicolumn{5}{|l|}{ Fixed Effect } \\
\hline 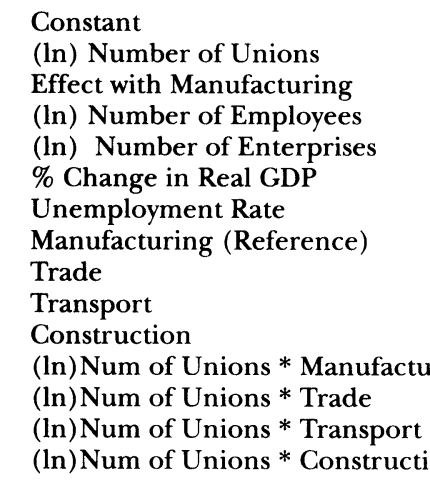 & ing & $\begin{array}{c}-2.295(0.96)^{* * *} \\
1.242(0.29)^{* * *}\end{array}$ & $\begin{array}{c}-3.612(2.9) \\
1.35(0.34)^{* * *} \\
\\
-0.122(0.22) \\
0.142(0.26) \\
-0.057(0.05) \\
0.121(0.23)\end{array}$ & $\begin{array}{c}-18.35(2.38)^{* * *} \\
\text { See Interaction } \\
\\
-0.091(0.22) \\
1.467(0.22)^{* * *} \\
-0.061(0.05) \\
0.127(0.04)^{* * *} \\
\\
-.0 .092(2.19) \\
2.278(2.18) \\
1.679(2.22) \\
1.422(0.71)^{* *} \\
0.179(0.36) \\
0.709(0.39)^{* *} \\
0.224(0.58)\end{array}$ \\
\hline \multicolumn{5}{|l|}{ Random Effect } \\
\hline $\begin{array}{l}\text { Variance at Country Level } \\
\text { Variance at Sector Level } \\
\text { Variance at Year Level }\end{array}$ & $\begin{array}{c}2.964(1.8)^{*} \\
1.643(0.54)^{* * *} \\
1.34(0.10)^{* * *}\end{array}$ & $\begin{array}{c}3.433(1.9)^{* *} \\
0.8412(0.29)^{* * *} \\
1.34(0.10)^{* * *}\end{array}$ & $\begin{array}{c}2.479(1.47)^{*} \\
0.8962(0.33)^{* * *} \\
1.317(0.11)^{* * *}\end{array}$ & $\begin{array}{c}0(0) \\
0.471(0.16)^{* * *} \\
1.363(0.11)^{* * *}\end{array}$ \\
\hline \multicolumn{5}{|l|}{ Improvement } \\
\hline $\begin{array}{l}\text { Compared to Model } 0 \text { Deviance } \\
\text { Change in Deviance } \\
\text { Change in df }\end{array}$ & 1266.63 & $\begin{array}{c}1254.2 \\
12.43^{* * *} \\
1\end{array}$ & $\begin{array}{c}1088.59 \\
178^{* * *} \\
6\end{array}$ & $\begin{array}{c}1062.81 \\
203.82^{* * *} \\
13\end{array}$ \\
\hline $\mathrm{N}$ & 376 & 376 & 326 & 326 \\
\hline
\end{tabular}

*Statistically significant at the .10 level; $* *$ at the .05 level; ***at the .01 level (one-tailed tests).

within countries, whereas the variance at the national level shows the differences in strike frequencies between countries. The variance at the year level shows the differences in strike frequencies within the seventeen-year time period. The sum of the variance at all levels is the total variance in the dependent variable. Inserting an explanatory variable may cause a change in any of the random effects. Finally, the third metric produced by the multi-level analysis is the deviance. Changes in deviance compared to the empty model can be tested by using a $\chi^{2}$ test to estimate the improvements in the model. Table 4 shows the results of the multi-level analysis.

The importance of sector-level factors is shown by the results of the empty model. This model, which includes no explanatory variables, shows the degree to which country-level factors and sector-level factors, respectively, are responsible for the variance in strike frequency. Although variance at the national level is higher, the sector-level variance accounts for almost one-third of the total variance, meaning that sector-level factors heavily condition the total variance in strike frequency. The variance at the lowest level-years-is also considerable and statistically significant.

Model 1 investigates the relationship between strike frequency and the number of labor unions. This parameter appears to be significant $(p<.01)$ and confirms the expected positive effect of the number of unions on strike frequency. The advantage of a multi-level analysis over an ordinary regression analysis is that it also informs us of the level at which variance is explained. This will answer the question of whether the effect of the number of labor unions is a sector-level effect or, as suggested by the comparative studies, a country-level effect. The key to answering this question is the decrease in variance at each level. Table 4 shows that the variance at the sector level has decreased. 
The fact that country-level variance has not decreased indicates that differences in strike frequencies between countries are not caused by the number of unions. The decrease in variance at the sector level indicates that the number of labor unions does affect strike frequency. The improvement of the model, based on the decrease in deviance, is statistically significant $(\mathrm{p}<.01)$.

To rule out the possibility that the relationship found between the number of unions and strike frequency is a reflection of sector size, in model 2 I control for the number of employees and the number of enterprises in the sector. ${ }^{11}$ The beta of both indicators for sector size appears not to be statistically significant. The same is true of the control variables for the business cycle. However, the reductions in variance seem to have effects at the national level and the year level. This indicates that the control variable explains differences in strike frequencies between countries and years rather than between sectors.

Finally, I test a model (model 3) in which the interaction effects between sector and the number of unions are included, in order to determine whether the impact of the number of unions on strike frequency differs across the four sectors. This model shows statistically significant interaction effects for manufacturing and transport. In the construction and trade sectors, the number of unions does not seem to affect strike incidence. The variables controlling for unemployment rate and number of enterprises become statistically significant when the analysis also controls for sector characteristics, which is to be expected since booms and recessions tend to be across sectors. The effect of the unemployment rate is counter-cyclical, meaning that strike

\footnotetext{
"Controlling for union density resulted in a drop of the $\mathrm{N}$ from 326 to 120 . Union density appeared to be significant at the 10 level (Beta $0.02(0.0013)$ ) in model 2 and not to have altered the effects of the other variables. In model 3, however, following introduction of the sector and interaction effects, the effect of union density dropped to zero, leaving the other variables essentially unchanged. The unchanged outcomes for the control and explanatory variables after a considerable drop in $\mathrm{N}$ indicate that the results are fairly stable.
}

incidence is higher when unemployment is higher. This is a remarkable finding, since most (Northern American) studies have reported a negative effect (Kaufman 1982; McConnell 1990; Franzosi 1995:30), although several exceptions have also been found (Gramm 1986; Ingram et al. 1993).

Multi-level analysis leads to two important conclusions. First, I have determined this effect to be a sector-level effect. Second, the number of labor unions appears to have an important effect on strike frequency not in all sectors, but in two. The effect is largest in manufacturing, a sector classified as having the most heterogeneous work force; this confirms the findings of British research (Dobson 1997). The effect is smaller, though still statistically significant, for transport, a sector classified as having medium heterogeneity. This, combined with the lack of the effect of the number of unions in the homogeneous construction sector, indicates that multi-unionism is related to the heterogeneity of occupational composition of the work force within sectors. This finding supports hypothesis I, which states that unions compete for primacy in bargaining, not for members. Weakening this tentative conclusion, however, is the finding that the number of unions has no effect in the trade sector, a sector that is also classified as having medium heterogeneity.

\section{Conclusion}

This article is aimed at reinvigorating the debate on the positive relationship between a divided labor movement and strike activity, a pattern first observed in international comparative research that has, to date, remained a puzzle for which no unequivocal explanation have been offered. Preliminary attempts to explain this relationship as reflecting a tendency of union rivalry to provoke strikes have failed to satisfactorily account for persistent anomalies. As a result, research into the matter has remained in something of a blind alley since the late 1970 s. Two shortcomings of research, one methodological and the other theoretical, have been responsible for the puzzle's longevity. First, the observed relationship has never been subjected to a 
sophisticated statistical test; and second, it has wrongly been identified as a nationallevel phenomenon, rather than a sector-level phenomenon. This article demonstrates that the investigation of strikes is more appropriately conducted at the sector level than at the national level.

The results of the statistical test performed in this study, using 17 years of strike data from four industrial sectors in seven European countries, confirm the relationship between the number of unions and strike frequency, and also show that this relationship is a sectorlevel rather than national-level phenomenon. The analysis indicates, too, an important dimension of inter-sectoral variation: the number of unions affects strike frequency in sectors with a heterogeneous work force, but not in more occupationally homogeneous sectors. These findings support the speculation that unions compete for primacy by bidding up bargaining claims, with elevated strike incidence as a byproduct; not supported is the claim that unions initiate strikes as a propaganda stratagem to attract membership from a pool of workers who have two or more unions to choose from.
Although this is an important improvement on previous comparative studies of the coincidence of high strike frequencies and divided labor movements, the puzzle is by no means solved yet, because even an investigation at the sector level leaves one anomaly unexplained: the trade sector. Although this sector is classified as having medium occupational heterogeneity, it seems to exhibit no competition over bargaining claims between the unions, or at least none that results in industrial conflict.

Summing up, I see this study as making two contributions. The more important of the two is the study's demonstration of the value of investigating the sector level to identify and explain patterns of strike activity, which suggests the advisability of adding a sub-national perspective to traditional comparative industrial relations research. Second, although the analysis presented here has not definitively settled the question of why multi-unionism is associated with higher strike incidence, it has at least provided some theoretical elaboration concerning the dynamics of that relationship, including the development of two testable hypotheses.

\section{REFERENCES}

Akkerman, Agnes. 1997. "A New Theory of Trade Union Competition." In Joe Wallace, Tam Dalzell, and Bernard Delany, eds., Continuity and Change in the Employment Relationship, pp. 231-46. Dublin: Oak Tree Press.

2000. Verdeelde Vakbeweging en Stakingen: Concurrentie om Leden. (Divided Labor Movement and Strikes: Competition for Members.) Amsterdam: Thesis.

Akkerman, Agnes, Rudi Wielers, and Gerrit Van Kooten. 1995. "Vakbondscoalities en Stakingen." (Union Coalitions and Strikes.) Tijdschrift voor Arbeidsvraagstukken, Vol. 11, No. 2, pp. 163-72.

Battista, Andrew. 1991. "Political Division in Organized Labor, 1968-1988.” Polity, Vol. 14, No. 2 (Winter), pp. 173-97.

$\rightarrow$ Britt, David W., and Omer R. Galle. 1972. "Industrial Conflict and Unionization." American Sociological Review, Vol. 37, No. 1 (February), pp. 46-57.

Campolieti, Michele, Robert Hebdon, and Douglas Hyatt. 2005. "Strike Incidence and Strike Duration: Some New Evidence from Ontario." Industrial and Labor Relations Review, Vol. 58, No. 4 (July), pp. 610-30.
Chaison, Gary N. 1996. Union Mergers in Hard Times: The View from Five Countries. Ithaca: Cornell University Press.

Clegg, Hugh A. 1976. Trade Unionism under Collective Bargaining: A Theory Based on Comparisons of Six Countries. London: Basil Blackwell.

Cohn, Samuel. 1993. When Strikes Make Sense-and Why: Lessons from Third RepublicFrench Coal Miners. New York and London: Plenum.

Cörver, Frank, Arnaud Dupuy, Sander Dijksma, Bart Goldsteyn, Ben Kriechel, and Raymond Moutizaan. 2006. "Methodiek Arbeidsprognoses en Indicatoren, 2005-2010." (Methods of Labor Market Prognoses and Indicators, 2005-2010.) Working paper, Research Center for Education and the Labour Market, Faculty of Economics and Business Administration, University of Maastricht, the Netherlands.

Crouch, Colin. 1982. Trade Unions: The Logic of Collective Action. London: Fontana.

Dobson, John R. 1997. "The Effects of Multi-Unionism: A Survey of Large Manufacturing Establishments." British Journal of Industrial Relations, Vol. 35, No. 4 
(December), pp. 547-66.

Ebbinghaus, Bernard. 1995. "The Development of Trade Unions in Western Europe: Global Convergence or Cross-National Diversity?” Eurodata Newsletter No. 2, pp. 1-8. http://www.mzes.uni-mannheim. de/eurodata/newsletter/no2/feature.html (accessed February 3, 2008).

Ebbinghaus, Bernard, and Jelle Visser. 2000. The Societies of Europe: Trade Unions in Western Europe Since 1945. Basingstoke: Macmillan.

Ebbinghaus, Bernard, and Jeremy Waddington. 2000. "United Kingdom/Great Britain." In Bernard Ebbinghaus and Jelle Visser, eds., The Societies of Europe: Trade Unions in Western Europe Since 1945, pp. 706-56. Basingstoke: Macmillan.

Edwards, Paul K., Mark Hall, Richard Hyman, Paul Marginson, Keith Sisson, Jeremy Waddington, and David Winchester. 1992. "Great Britain: Still Muddling Through." In Anthony Ferner and Richard Hyman, eds., Industrial Relations in the New Europe, pp. 1-68. Oxford: Blackwell.

Edwards, Paul K., and Richard Hyman. 1994. "Strikes and Industrial Conflict: Peace in Europe?" In Richard Hyman and Anthony Ferner, eds., New Frontiers in European Industrial Relations, pp. 250-80. Oxford: Blackwell.

ETUI-REHS (European Trade Union Institute for Research Education and Health and Safety). 2007. "Worker Representation in Europe." http://www. worker-participation.eu/national_industrial_rela tions/across_europe/workplace_representation_1 (accessed February 4, 2008).

Eurofound (European Foundation for the Improvement of Living and Working Conditions). 2006. "Union Membership and Density Levels in Decline." http:// www.eurofound.europa.eu/eiro/2006/03/articles/ eu0603029i.html (accessed February 4, 2008).

2007. "Industrial Relations in EU Member States, 2000-2004." http://www.eurofound.europa. $\mathrm{eu} / \mathrm{publications} / \mathrm{htmlfiles} / \mathrm{ef0715}$.htm (accessed February 4, 2008).

Franzosi, Roberto. 1989. "One Hundred Years of Strike Statistics." Industrial and Labor Relations Review, Vol. 42, No. 3 (April), pp. 34-63.

1995. The Puzzle of Strikes: Class and State Strategies in

Postwar Italy. New York: Cambridge University Press.

Freeman, John, and Jack Brittain. 1977. "Union Merger Process and Industrial Environment." Industrial Relations, Vol. 16, No. 2 (May), pp. 173-85.

Galenson, Walter. 1940. Rival Unionism in the United States. New York: Russell \& Russell.

Gitlow, Abraham L. 1952. "Union Rivalries." SouthernEconomic Journal, Vol. 18, No. 3 (January), pp. 338-49.

Gould, William B. 2004. A Primer on American Labor Law. Cambridge and London: MIT Press.

$\rightarrow$ Gramm, Cynthia L. 1986. "The Determinants of Strike Incidence and Severity: A Micro-Level." Industrial and Labor Relations Review, Vol. 39, No. 3 (April), pp. 361-76.

Hicks, John R. 1963. Theory of Wages. New York: St. Martin's.

Hyman, Richard. 1988. Strikes. London: Macmillan. ILO. 1997, 2006. Yearbook of Labour Statistics. Geneva:
ILO.

Ingram, Peter, David Metcalf, and Jonathan Wadsworth. 1993. "Strike Incidence in British Manufacturing in the 1980s." Industrial and Labor Relations Review, Vol. 46, No. 4 (July), pp. 704-17.

Kaufman, Bruce E. 1982. "Bargaining Theory, Inflation, and Cyclical Strike Activity." Industrial and Labor Relations Review, Vol. 34, No. 3 (April), pp. 333-55.

$\rightarrow$ Korpi, Walter, and Michael Shalev. 1979. "Strikes, Industrial Relations, and Class Conflict in Capitalist Societies." British Journal of Sociology, Vol. 30, No. 2 (June), pp. 164-87.

$\rightarrow$ Krislov, Joseph. 1960. "Organizational Rivalry among American Unions." Industrial and LaborRelations Review, Vol. 13, No. 2 (January), pp. 216-26.

Lester, Richard A. 1958. As Unions Mature: An Analysis of the Evolution of American Trade Unionism. Princeton: Princeton University Press.

Lijphart, Arend. 1968. The Politics of Accommodation: Pluralism and Democracy in the Netherlands. Berkeley: University of California Press.

Machin, Stephen, Mark Stewart, and John van Reenen. 1993. "The Economic Effects of Multiple Unionism: Evidence from the 1984 Workplace Industrial Relations Survey." Scandinavian Journal ofEconomics, Vol. 95, No. 3 (September), pp. 297-96.

Martin, Roderick. 1992. Bargaining Power. Oxford: Clarendon.

$\rightarrow$ McConnell, Sheena. 1990. "Cyclical Fluctuations in Strike Activity." Industrial and Labor Relations Review, Vol. 44, No. 1 (October), pp. 130-43.

OECD. 2004, 2007. Employment Outlook. Paris.

$\rightarrow$ Oswald, Andrew J. 1979. "Wage Determination in an Economy with Many Trade Unions." Oxford Economic Papers, Vol. 31, No. 3 (May), pp. 369-85.

$\rightarrow$ Pohjola, Matti. 1984. "Union Rivalry and Economic Growth: A Different Game Approach." Scandinavian Journal of Economics, Vol. 86, No. 3 (September), pp. 365-70.

Ross, Arthur H., and Paul Hartman. 1960. Changing Patterns of Industrial Conflict. New York and London: John Wiley \& Sons.

$\rightarrow$ Ross, Arthur H., and Donald Irwin. 1951. "Strike Experience in Five Countries, 1927-1947: An Interpretation." Industrial and Labor Relations Review, Vol. 4, No. 3 (April), pp. 323-42.

Snijders, Tom A. B., and Robert J. Bosker. 1999. Multilevel Analysis: An Introduction to Basic and Advanced Multilevel Modeling. London: Sage.

Stewart, Mark. 1987. "Collective Bargaining Arrangements, Closed Shops, and Relative Pay." Economic Journal, Vol. 97, No. 385 (March), pp. 140-56.

Stokke, Torgeir A., and Christer Thörnqvist. 2001. "Strikes and Collective Bargaining in the Nordic Countries." European Journal of Industrial Relations, Vol. 7, No. 3, pp. 245-67.

Stout, Sarah K. 1995. "Union Competition to Organize Healthcare Workers, 1972 to 1991.” Diss., Cornell University.

Traxler, Franz, Sabine Blaschke, and Bernhard Kittel. 2001. National Labour Relations in International Markets: A Comparative Study of Institutions, Change, and Performance. Oxford: Oxford University Press. 
Visser, Jelle. 1987. "In Search of Inclusive Unionism: A Comparative Analysis." Diss., University of Amsterdam.

1992. "The Strength of Union Movements in Advanced Capital Democracies: Social and Organizational Variations." In Marino Regini, ed., The Future of
Labour Movements, pp. 17-52. London: Sage.

Webb, Sidney, and Beatrice Webb. 1897. Industrial Democracy. London: Longmans, Green.

$\rightarrow$ Wheeler, Hoyt N. 1984. "Determinants of Strikes: Comment." Industrial and Labor Relations Review, Vol. 37, No. 2 (January), pp. 263-69. 